\title{
Effect of Hippophae rhamnoides L. Leaves Treatment on the Antioxidant Capacity, Total Phenol Content and Sensory Profile of Moschofilero Wines Vinified with and without Added Sulphites
}

\author{
Alexandros Tzachristas ${ }^{1}$, Konstantina Pasvanka ${ }^{1}$, Maria Liouni ${ }^{1}$, Antony C. Calokerinos ${ }^{1}$ (D), \\ Panagiotis Tataridis ${ }^{2}$ and Charalampos Proestos $1, *$ (D) \\ 1 Department of Chemistry, National and Kapodistrian University of Athens, 15784 Athens, Greece; \\ A.Tzachristas@chem.uoa.gr (A.T.); pasvankakon@chem.uoa.gr (K.P.); mliouni@chem.uoa.gr (M.L.); \\ calokerinos@chem.uoa.gr (A.C.C.) \\ 2 Department of Wine, Vine and Beverage Sciences, University of West Attica, Panepistimioupoli 1, \\ 12234 Egaleo, Greece; ptataridis@uniwa.gr \\ * Correspondence: harpro@chem.uoa.gr; Tel.: +30-2107274160; Fax: +30-2107274476
}

Received: 9 April 2020; Accepted: 13 May 2020; Published: 16 May 2020

\begin{abstract}
This study evaluated the antioxidant capacity, total phenol content, and sensory profile of selected Greek wines made from Vitis vinifera L. c.v. Moschofilero in two consecutive vintages, treated with powdered Hippophae rhamnoides L. leaves (HRL). Radical Scavenging activity, reducing power, total phenol content (TPC), and color intensity increased in a linear manner in relation to HRL treatments. Indicatively the addition of $0.8 \mathrm{~g} / \mathrm{L}$ of HRL increased the radical scavenging activity as determined via the inhibition of the 2,2-diphenyl-1- picrylhydrazyl (DPPH) radical from 28.4 to $55.8 \%$ in comparison to the initial values. Equally the reducing power as determined by the ferric reducing antioxidant power (FRAP) assay increased from 35.3 to $62.1 \%$, and total phenol content values increased from $11 \%$ to $23.7 \%$ and the color intensity increased from 39.9 to $50.7 \%$. The main oenological attributes examined, remained unchanged after the HRL addition. The addition of up to $0.4 \mathrm{~g} / \mathrm{L}$ of HRL did not have a major impact on the organoleptic characteristics of the wines tasted whereas concentrations higher than $0.8 \mathrm{~g} / \mathrm{L}$ were not considered beneficial. Results denote that the addition of $H$. rhamnoides leaves to white wines contributes positively to the overall antioxidant capacity and could be used if authorized as an antioxidant agent in wines vinified in the absence of or in synergy with sulphur dioxide.
\end{abstract}

Keywords: white wine; antioxidant capacity; Hippophae rhamnoides L. leaves; sulphur dioxide

\section{Introduction}

Wine is considered as one of the most important dietary sources of antioxidants for the human body. The antioxidant capacity of wines is mainly attributed to flavonoid and non-flavonoid compounds [1-3] macerated and/or produced during the alcoholic fermentation even though in certain cases the contribution of exogenous added antioxidants such as $\mathrm{SO}_{2}$ and ascorbic acid has been found higher than the naturally existing antioxidants $[4,5]$. The polyphenolic content in white wines is generally lower than red wines, consisting mainly of hydroxycinammic acids which are significantly crucial in oxidation related issues such as browning and flavor deterioration [6]. The contribution of the polyphenolic content on the overall antioxidant capacity in wines with sulphur dioxide additions (further down also referred to as conventional) is often overestimated due to the presence of sulphur dioxide [7]. 
Sulphur dioxide or $\mathrm{SO}_{2}$ is the most widely used additive in the wine industry. The addition of sulphur dioxide in wine, inhibits oxidation and the growth of spoilage microorganisms, augments pigment extraction, and reduces the polymerization of phenolics [8] making it an indispensable partner of the vinification process. Nevertheless the use of sulphur dioxide has been regulated due to allergic reactions observed on hypersensitive individuals $[9,10]$. Furthermore the excessive use of sulphur dioxide raises qualitative issues since it has been involved in the presence of off flavors [11] and in haze formation [12]. Currently there is a tendency of reducing the levels or replacing sulphites salts in order to produce minimum interventions wines and this is becoming relatively feasible with the use of physical and/or chemical methods. Main efforts rely on the addition of compounds such as phenolic compounds preparations, dimethyl dicarbonate, and bactiriocins but also on physical treatments such as the application of pulsed electric fields, ultrasounds, UV radiation, and high pressure [13-16].

Hippophaë rhamnoides L. (Elaeagnaceae), also mentioned as sea buckthorn, is an Eurasian nitrogen-fixing actinomycetes plant species, bearing yellow or orange berries which has been used for centuries in both Europe and Asia for nutritional, therapeutic, and pharmaceutical purposes [17]. Apart from the berries and seeds, H. rhamnoides leaves (HRL) have recently gained interest for their antimicrobial and antioxidant properties [18-20] and for various health promoting properties such as anti-inflammation, immunomodulation, radioprotection, and tissue regeneration [21-23]. $H$. rhamnoides leaves are considered of remarkably high nutraceutical value and this is attributed to the presence of important bioactive compounds and nutrients. Chemical composition of the leaves has been thoroughly described, comprising of various classes of phenolic compounds, tocopherols, proteins, aminoacids, fatty acids, organic acids, and mineral elements [17,24-27]. Specifically, regarding their polyphenolic content, the leaves have been found to be rich in flavonol glucosides (15 times richer than the berries) [25], phenolic acids, and ellagitannins [17]. Their high nutritional value and the absence of cytotoxicity as indicated by relevant studies $[21,28,29]$ has permitted the exploitation of the leaves in the food and feed industry $[18,30]$. However, the leaves continue to be underutilized and are still considered as a by-product during berry harvesting and pruning despite their significant bioactive potential.

In recent years, the possible use of natural by-products and residues rich in valuable bioactive matter in order to enhance the properties of other goods is highly appreciated by consumers. This practise is regarded to present a competitive advantage and result in an increased added value of the final product [31]. It is essential nonetheless to define the nutraceutical value of the final products in order to gain in depth knowledge of their properties. Antioxidant studies aiming at this direction, including the 2,2-diphenyl-1- picrylhydrazyl (DPPH) and ferric reducing antioxidant power (FRAP) assays, have been widely applied as they are relatively simple, reliable, fast, and efficient methods in determining the antioxidant capacity $[4,5,22]$.

In this context, the evaluation of increasing HRL treatments as an alternative means to increase the antioxidant capacity of wines has not been previously explored. The aim of this study was to investigate the effect of this novel approach on the antioxidant capacity, total phenol content (TPC) and organoleptic characteristics of wines vinified in the presence or absence of commonly added antioxidants.

\section{Materials and Methods}

\subsection{Chemicals and Equipment}

DPPH, methanol, sodium acetate, iron(iii) chloride, Trolox (6-hydroxy-2,5,7,8-tetramethylchromane -2-carboxylic acid), and ascorbic acid were purchased from Chem-Lab NV (Zedelgem, Belgium). Gallic acid and hydrochloric acid were obtained from Sigma-Aldrich (St. Louis, MO, USA), 2,4,6-Tri(2-pyridyl)-1,3,5-triazine (TPTZ) from Alfa Aesar (Karlsruhe, Germany), Glacial acetic acid from Carlo Erba (Milan, Italy) and Folin-Ciocalteu Reagent (wine det.) was purchased from Merck (Darmstadt, Germany).

All reagents and solvents used in this study were of HPLC or analytical grade. 
Absorbance measurements were conducted on a UV-visible spectrophotometer (UV mini-1240, Shimadzu, Kyoto, Japan).

\subsection{Collection and Preparation of Plant Material}

The HRL were collected in 2014 (Sep 2014) from the plant crop in ELGO-Dimitra (www.elgo.gr, former NAGREF, http://www.nagref.gr/) in the region of Lykovrisi, Attica, Greece where the plant grows experimentally under natural conditions (non-heated, uncovered greenhouse). Plant material was characterized by Dr. P. Zamanidis researcher in ELGO-Dimitra, Greece, where specimens were kept. Fresh leaves were hand sorted, washed and cleaned thoroughly with water and rewashed with nanopure water. Subsequently they were dried at $55{ }^{\circ} \mathrm{C}$ to $3 \%$ of relative humidity with a Binder ED 115 oven (Binder, Tuttlingen, Germany) and grinded into powder using a laboratory blender. The leaves were kept in airtight sterile glass containers and stored at $4{ }^{\circ} \mathrm{C}$ until use. In order to prevent from possible cross-contamination, clean and sterile conditions were maintained throughout the whole preparation process.

\subsection{Vinification of Wine Samples}

All grapes belonged to Moschofilero cv. (Vitis vinifera L.), were sourced from Arcadia, Peloponese, Southern Greece and vinifications were conducted in the winery of the Boutari s.a (Mantineia, Greece) in the same region. Moschofilero is a pink-skinned grape variety producing aromatically expressive medium bodied wines high in terpene content. Four white dry wines were produced in two equally sized batches each, resulting from the vinification in duplicate of approximately $1500 \mathrm{~kg}$ of local grapes as follows: 2 dry wines from 2 consecutive vintages $(2014,2015)$ of the same vineyard, vinified with and without sulphur dioxide addition from c.v. Moschofilero grapes referred to as nas14, nas 15 for no added sulphites vinifications and con14, con15 for conventional vinifications (Table 1).

Table 1. Characterization and vinification notes of wine samples.

\begin{tabular}{|c|c|c|c|c|}
\hline Sample Code & Variety & Region & Vintage Year & Vinification \\
\hline nas 14 & Moschofilero & Arcadia & 2014 & $\begin{array}{c}\text { No Sulphites added. } 6 \text { months maturation } \\
\text { in stainless steel tanks }\end{array}$ \\
\hline nas 15 & Moschofilero & Arcadia & 2015 & $\begin{array}{c}\text { No Sulphites added. } 6 \text { months maturation } \\
\text { in stainless steel tanks }\end{array}$ \\
\hline con 14 & Moschofilero & Arcadia & 2014 & $\begin{array}{c}\text { Conventional. } 6 \text { months maturation in } \\
\text { stainless steel tanks }\end{array}$ \\
\hline con15 & Moschofilero & Arcadia & 2015 & $\begin{array}{c}\text { Conventional. } 6 \text { months maturation in } \\
\text { stainless steel tanks }\end{array}$ \\
\hline
\end{tabular}

Grapes were manually harvested at optimum technological maturity for each variety (20-24 Brix), placed in small plastic containers and transferred immediately to the winery for the vinification process.

Upon receival, the grapes were immediately destemmed and crushed, and during transfer the grape juice was treated with sulphur dioxide $(50 \mathrm{mg} / \mathrm{L})$ to avoid must oxidation except for musts intended for vinifications without added sulphites. The mass was gently pressed under a dry ice blanket (30 mm pellets, $10 \mathrm{~kg}$ pellets $/ 1000 \mathrm{~kg}$ grapes), $2 \mathrm{~g} / 100 \mathrm{~L}$ of pectolytic enzymes were added (Depectil Clarification FCE) and the must was left to settle for $24 \mathrm{~h}$ at $10^{\circ} \mathrm{C}$. After clarification and under $\mathrm{CO}_{2}$ blanket, clear juice was transferred to the fermentation tanks where $20 \mathrm{~g} / 100 \mathrm{~L}$ of yeast nutrients (Actiferm 1, Martin Viallatte, France) were added and the fermentation was quickly induced via inoculation of previously activated ( $24 \mathrm{~h}$ before) Saccharomyces cerevisiae (Vitilevure 58W3 YSEO, Martin Viallatte, France) starter culture ( $20 \mathrm{~g} / 100 \mathrm{~L})$. Fermentation was carried out in temperature-controlled stainless-steel tanks at $15-17^{\circ} \mathrm{C}$ and lasted about 20 days with a complete consumption of the reducing sugars. One week after the end of alcoholic fermentation for conventional vinifications and one week after the end of the spontaneous malolactic fermentation for vinifications without added sulphites, the wines were separated from their lees and racked off into clean containers. 
After the maturation phase the wines were further settled using a complex plant protein-based fining allergen free agent (ProvGreen Pure Wine, Martin Vialatte, France) (10 g/100 L), and granular sodium bentonite $(80 \mathrm{~g} / \mathrm{hL})$. After cold stabilization the wines were racked off, filtered $(0.65 \mu \mathrm{m})$, and bottled under nitrogen atmosphere using a gravity filler.

In order to avoid macro-oxygenation and oxidation, all must and wine transfers, during the whole winemaking process until bottling, were made by previous saturation of pipes and tanks with a mixture of carbon dioxide and nitrogen.

\subsection{H. rhamnoides Leaves Treatment}

Chemical composition, antioxidant and antimicrobial properties of HRL have been previously reported [19,22]. Ranges of major phenolic compounds identified in HRL in previous studies are presented in Table 2.

Table 2. Major phenolic compounds previously identified in H. rhamnoides leaves.

\begin{tabular}{|c|c|c|}
\hline Compounds/Class & nge (mg/Kg DW) & References \\
\hline \multicolumn{3}{|c|}{ Carotenoids } \\
\hline Zeaxanthin & $5-6$ & [32] \\
\hline Violaxanthin & $5-6$ & [32] \\
\hline Lutein & $8-11$ & [32] \\
\hline Zeaxanthin & ND-6 & [32] \\
\hline$\beta$-Carotene & $7-9$ & [32] \\
\hline \multicolumn{3}{|c|}{ Flavonol Glucosides } \\
\hline Q-3-O-rutinoside/Rutin & $471-1310$ & [24] \\
\hline Q-3-O-galactoside & $205-458$ & [24] \\
\hline Q-3-O-sorphroside-7-O-rhamnoside & $301-359$ & [25] \\
\hline I-3-O-rutinoside & $107-496$ & [25] \\
\hline I-3-O-rutinoside-7-O-glucoside & $405-1146$ & [25] \\
\hline I-3-O-sophroside-7-O-rhamnoside & $250-446$ & [25] \\
\hline I-3-O-glucoside & $254-339$ & [25] \\
\hline I-3-O-glucoside-7-O-rhamnoside & $691-1110$ & [25] \\
\hline I-3-O-neohesperidoside & $585-1639$ & [25] \\
\hline K-3-O-glucoside & $56-101$ & [24] \\
\hline K-3-O-rutinoside & $291-894$ & [25] \\
\hline Quercetin & $332-1381$ & [24] \\
\hline Kaempferol & $2.8-4.1$ & [24] \\
\hline Gallic acid & $19.1-79.1$ & [33] \\
\hline Caffeic acid & $5.9-9.8$ & [33] \\
\hline p-coumaric acid & $8.4-13.4$ & [33] \\
\hline Ferulic acid & $7.2-15.1$ & [33] \\
\hline \multicolumn{3}{|c|}{ Ellagitanins } \\
\hline Pedunculagin & $220-510$ & [18] \\
\hline Stachyurin & $2400-4330$ & [18] \\
\hline Hippophaenin C & $1250-3360$ & [18] \\
\hline Casuarinin & $2820-4630$ & [18] \\
\hline Hippophaenin B & 930-1000 & [18] \\
\hline Casuarictin & $3170-4700$ & [18] \\
\hline
\end{tabular}

$\mathrm{ND}=$ not detected; DW = dry weight; I = Isorhamnetin; $\mathrm{Q}=$ Quercetin, $\mathrm{K}$ = kaempferol. 
Powdered HRL were added in increasing quantities $(0.00-0.13-0.40-0.80-1.07-1.60 \mathrm{~g} / \mathrm{L})$, the wines were capped using a technical stopper under nitrogen atmosphere and left to macerate for 7 days at $20^{\circ} \mathrm{C}$. Since the treatment with $\mathrm{H}$. rhamnoides leaves is not an authorized practice according to EC Regulation 936/2019 [34] and in the absence of literature data on the wine and HRL maceration conditions, a midway approach was adopted in relation to the maceration conditions. We considered that a higher temperature-lower duration scheme such as the herbal infusion maceration scheme may have had a detrimental effect on the sensory profile of the white wines [35] while a lower temperature than the one selected might have reduced the extractability of the bioactive matter. Hence, we selected a strategy that resembled a red vinification scheme or the treatment with oak chips in wine. However, we believe that further optimization studies should be scheduled regarding to the wine and HRL maceration conditions.

After the end of the maceration period the wines, including the control samples, were filtered through a 0.45 PTFE filter to ensure the complete removal of the leaves and stored at $4{ }^{\circ} \mathrm{C}$ until the day of analysis. The treatments were replicated in triplicate in each batch. All determinations thereafter were conducted in triplicate.

\subsection{Main Oenological Attributes}

The wine samples were characterized regarding to some common oenological characteristics related to wine quality with the aid of an NIR spectrometer (FOSS, NIR Systems, Inc., EL Leende, The Netherlands). Free and total $\mathrm{SO}_{2}$ were determined according to OIV methods of Analysis [36].

\subsection{Sensory Evaluation}

Sensory evaluation was conducted according to Castillo-Sánchez et al. [37] with minor modifications in the same month as the analysis. The tasting was held in a tasting room following ISO 8589:2007 guidelines with standard ISO 3591:1977 tasting glasses by a panel of 8 trained wine professionals (4 male and 4 female, ages 30-65 yo). Treated wine samples were characterized with a three-digit code number, were provided in adequate temperature $\left(12{ }^{\circ} \mathrm{C}\right)$ and in random order. Initially the panel tasted two synthetic wines $(12 \%$ vol, $6 \mathrm{~g} / \mathrm{L}$ Tartaric acid) treated with the lowest and highest HRL dosage in order to become familiar with the HRL sensory attributes. Consecutively all the samples were tasted and rated on a 0-10 scale based on specific descriptors for their appearance (color intensity), odor (intensity, fruit, vegetative), and taste (body and mouthfeel, balance, fruit, and aftertaste).

\subsection{DPPH Assay}

The determination of free radical scavenging activity by means of the Inhibition (I) of the DPPH radical is based on the quenching of the DPPH radical by antioxidants present in the wine samples. The antioxidant capacity of wines by the DPPH free radical scavenging method was determined following Porgali and Büyüktuncel, (2012) [38] with minor modifications. The procedure consists of adding $33 \mu \mathrm{L}$ of wine, diluted in methanol, to $967 \mu \mathrm{L}$ of a DPPH radical methanolic solution $\left(6 \times 10^{-5} \mathrm{~mol} / \mathrm{L}\right)$, and after $30 \mathrm{~min}$ in the dark, measuring the percentage of absorbance decrease at $515 \mathrm{~nm}$. The percentage inhibition of initial concentration of DPPH·radical was calculated as [39]:

$$
\% \text { Inhibition }=\left[\left(\mathrm{A}_{\mathrm{DPPH}}-\mathrm{A}_{\text {wine }}\right) / \mathrm{A}_{\mathrm{DPPH}}\right] \times 100
$$

Quantification of the antiradical activity $\left(\mathrm{A}_{\mathrm{AR}}\right)$ was made by calibration curves obtained from methanolic solutions of trolox, and the results were expressed in $\mathrm{mM}$ Trolox equivalents (TE).

\subsection{Ferric Reducing Antioxidant Power (FRAP) Assay}

The reducing power of the samples was determined according to the method described by Benzie and Strain (1996) [40], with minor modifications. In this assay Fe(III) oxidizes wine antioxidants 
and the amount of Fe(II) produced is measured spectroscopically [41]. The Fe(II) selective ligand, 2,4,6-tripyridyl-s-triazine (TPTZ) is added which produces a colored Fe(II) complex that can be quantified spectroscopically at $593 \mathrm{~nm}$ and raises the reduction potential of $\mathrm{Fe}(\mathrm{III}) / \mathrm{Fe}(\mathrm{II})$ couple [41]. Procedure consists of mixing $30 \mu \mathrm{L}$ of diluted wine (1:5 for white wines) and $90 \mu \mathrm{L}$ water with $900 \mu \mathrm{L}$ of freshly prepared, preincubated to $37^{\circ} \mathrm{C}$ FRAP reagent, obtained by mixing $300 \mathrm{mM}$ acetate buffer (pH 3.6), $10 \mathrm{mM}$ TPTZ (2,4,6-tripyridyl-s-triazine) solubilized in $40 \mathrm{mM} \mathrm{HCl}$, and $20 \mathrm{mM} \mathrm{FeCl}_{3}$ in a 10:1:1 ratio. Absorbance of the mixture was measured at $593 \mathrm{~nm}$ after $30 \mathrm{~min}$ and was deducted from the initial absorbance (M1) of FRAP Reagent. A calibration plot was generated based on known concentrations of Trolox; the results were expressed as $\mathrm{mM}$ Trolox equivalents.

\subsection{Determination of Total Phenol Content}

The total phenol content was determined using the Folin-Ciocalteu (F-C) method, as described by Singleton and Rossi (1965) [42]. The F-C Method is a widely used method for the analysis of total phenolics in wine which has the advantage of a fairly equivalent response to different phenols, with the disadvantage of responding to sulfur dioxide and sugar. Total phenol content via the F-C method was determined without previous preparation of the samples since the interference of sugar has been found negligible for most dry wines containing $<1 \%$ sugar [43]. The F-C reagent comprises of a phosphotungstate-molybdate complex, which on reduction by phenolic compounds in a one or two electron process produces a blue product with an absorbance maximum at $765 \mathrm{~nm}$. A calibration plot was generated based on known concentrations of Gallic acid. Results were expressed as mg/L Gallic acid equivalents (GAE).

\subsection{Statistical Analysis}

Data are expressed as Mean \pm SD of three parallel measurements. Correlation analysis between HRL treatments and antioxidant properties of wine samples was performed by means of Pearson correlation coefficient. Repeated measures Analysis of variance using Tukey HSD post-hoc test was conducted for each assay to determine differences among treated wine samples for all parameters examined using the R language [44]. Data visualization was performed using the "ggplot2" package [45]. $p<0.05$ was regarded as statistically significant.

\section{Results and Discussion}

\subsection{Main Oenological Parameters}

Main oenological parameters were determined to study the effect of HRL treatment on the selected wines. Table 3 depicts the main oenological attributes for control samples and samples with highest HRL dose treatment. Apart from color intensity, no statistically significant differences were observed between the wines studied, indicating that the treatment with the leaves did not alter the studied characteristics of the wines. The differences in total and volatile acidity values for all treatments between sulphited and non sulphited samples occurred possibly due to conduct of spontaneous malolactic fermentation in the case of non sulphited wines. Color intensity values in all samples increased in a linear manner due to the HRL treatments as depicted in Table 4. Values of alcohol content, total and volatile acidity, $\mathrm{pH}$ and sugar are in accordance with previously published data for Greek white wines [46,47].

Free radical scavenging activity $\left(\mathrm{A}_{\mathrm{AR}}\right)$, Ferric reducing power (FRP), and the total phenolic content (TPC), prior and after HRL treatments are presented in Table 4. 
Table 3. Main oenological parameters of wine samples prior and after highest H. rhamnoides leaves (HRL) treatment.

\begin{tabular}{|c|c|c|c|c|c|c|c|c|c|c|c|}
\hline Code & $\mathrm{HRL}^{\mathrm{a}}$ & Free $\mathrm{SO}_{2}{ }^{\mathrm{b}}$ & Total $\mathrm{SO}_{2}{ }^{\mathrm{b}}$ & $\mathrm{TA}^{\mathrm{c}}$ & $V^{d}$ & $\mathrm{pH}$ & D & $\%$ Vol & Extract ${ }^{e}$ & Sugar ${ }^{b}$ & $\mathrm{~A} 420^{\mathrm{f}}$ \\
\hline nas & Ctrl & 0 & 9 & 4.9 & 0.65 & 3.40 & 0.991 & 11.6 & 19.36 & 1.9 & 0.075 \\
\hline 14 & 1.6 & 0 & 10 & 5.0 & 0.72 & 3.41 & 0.991 & 11.6 & 19.92 & 2.2 & 0.145 \\
\hline nas & Ctrl & 0 & 10 & 5.2 & 0.57 & 3.38 & 0.991 & 11.3 & 20.35 & 1.2 & 0.126 \\
\hline 15 & 1.6 & 0 & 10 & 5.1 & 0.55 & 3.39 & 0.991 & 11.3 & 20.6 & 1.1 & 0.207 \\
\hline con & Ctrl & 32 & 94 & 5.5 & 0.28 & 3.31 & 0.991 & 11.6 & 19.48 & 1.8 & 0.064 \\
\hline 14 & 1.6 & 29 & 92 & 5.6 & 0.31 & 3.25 & 0.992 & 11.6 & 19.85 & 1.8 & 0.112 \\
\hline con & Ctrl & 29 & 115 & 5.5 & 0.31 & 3.27 & 0.991 & 11.3 & 22.91 & 2.7 & 0.048 \\
\hline 15 & 1.6 & 26 & 113 & 5.8 & 0.28 & 3.27 & 0.991 & 11.3 & 22.87 & 2.6 & 0.092 \\
\hline
\end{tabular}

Values are means of triplicate determination of each 1 of 3 bottles treated in each HRL concentration ( $\mathrm{n}=18)$. Abbreviations: ctrl: control samples; D: Density; a : HRL: H. rhamnoides leaves treatment expressed in $\mathrm{g} / \mathrm{L}^{b}$ : Values expressed in $\mathrm{mg} / \mathrm{L}^{\mathrm{c}}{ }^{\mathrm{c}}$ : Total Acidity (TA) expressed in $\mathrm{g} / \mathrm{L}$ tartaric acid; ${ }^{\mathrm{d}}$ : Volatile Acidity (VA) expressed in $\mathrm{g} / \mathrm{L}$ acetic acid; ${ }^{\text {e: }}$ Values expressed in $\mathrm{g} / \mathrm{L}$; f: Values expressed as absorbance units measured at a wavelength of $420 \mathrm{~nm}$. 
Table 4. Antiradical Activity $\left(\mathrm{A}_{\mathrm{AR}}\right)$, Ferric reducing antioxidant power (FRAP), Total phenol Content (TPC) and color intensity (A420) of wine samples prior and after the addition of increasing quantities of $H$. rhamnoides leaves.

\begin{tabular}{|c|c|c|c|c|c|}
\hline Sample Code & HRL Dosage & $\mathbf{A}_{\mathrm{AR}}$ & FRAP & TPC & A420 \\
\hline \multirow{6}{*}{ nas 14} & 0.00 & $0.49^{a} \pm 0.01$ & $1.23^{a} \pm 0.09$ & $233^{a} \pm 7$ & $0.075^{\mathrm{a}} \pm 0.004$ \\
\hline & 0.13 & $0.55^{\mathrm{ab}} \pm 0.01$ & $1.40^{\mathrm{a}} \pm 0.08$ & $250^{\mathrm{ab}} \pm 7$ & $0.082^{a} \pm 0.003$ \\
\hline & 0.40 & $0.59^{b} \pm 0.01$ & $1.66^{b} \pm 0.10$ & $269^{b c} \pm 7$ & $0.092^{b} \pm 0.003$ \\
\hline & 0.80 & $0.65^{c} \pm 0.02$ & $1.99^{b c} \pm 0.04$ & $280^{\mathrm{cd}} \pm 11$ & $0.109^{c} \pm 0.003$ \\
\hline & 1.07 & $0.75^{d} \pm 0.02$ & $2.09^{c} \pm 0.03$ & $301^{\mathrm{d}} \pm 8$ & $0.115^{c} \pm 0.003$ \\
\hline & 1.60 & $0.84^{e} \pm 0.02$ & $2.49^{d} \pm 0.07$ & $337^{\mathrm{e}} \pm 5$ & $0.145^{\mathrm{d}} \pm 0.003$ \\
\hline \multirow{6}{*}{ nas 15} & 0.00 & $0.37^{a} \pm 0.01$ & $1.13^{a} \pm 0.03$ & $220^{\mathrm{a}} \pm 4$ & $0.126^{a} \pm 0.007$ \\
\hline & 0.13 & $0.45^{b} \pm 0.01$ & $1.19^{a} \pm 0.02$ & $227^{a} \pm 10$ & $0.127^{a} \pm 0.003$ \\
\hline & 0.40 & $0.46^{b} \pm 0.02$ & $1.56^{b} \pm 0.03$ & $235^{a} \pm 7$ & $0.142^{b} \pm 0.004$ \\
\hline & 0.80 & $0.57^{\mathrm{c}} \pm 0.01$ & $1.69^{b} \pm 0.04$ & $272^{b} \pm 6$ & $0.173^{c} \pm 0.005$ \\
\hline & 1.07 & $0.63^{\mathrm{d}} \pm 0.01$ & $1.85^{\mathrm{c}} \pm 0.03$ & $290^{b c} \pm 8$ & $0.181^{c} \pm 0.002$ \\
\hline & 1.60 & $0.74^{\mathrm{e}} \pm 0.04$ & $2.24^{\mathrm{d}} \pm 0.07$ & $317^{c} \pm 12$ & $0.186^{c} \pm 0.007$ \\
\hline \multirow{6}{*}{ con 14} & 0.00 & $0.59^{a} \pm 0.01$ & $1.57^{a} \pm 0.06$ & $293^{a} \pm 6$ & $0.064^{a} \pm 0.002$ \\
\hline & 0.13 & $0.66^{\mathrm{ab}} \pm 0.04$ & $1.68^{\mathrm{ab}} \pm 0.04$ & $300^{a} \pm 6$ & $0.069^{\mathrm{ab}} \pm 0.004$ \\
\hline & 0.40 & $0.70^{b} \pm 0.03$ & $1.90^{b} \pm 0.05$ & $314^{\mathrm{ab}} \pm 6$ & $0.076^{b} \pm 0.002$ \\
\hline & 0.80 & $0.78^{c} \pm 0.02$ & $2.26^{\mathrm{c}} \pm 0.15$ & $334^{\mathrm{b}} \pm 8$ & $0.090^{\mathrm{c}} \pm 0.004$ \\
\hline & 1.07 & $0.81^{\mathrm{c}} \pm 0.01$ & $2.33^{c} \pm 0.21$ & $340^{b} \pm 20$ & $0.099^{\mathrm{d}} \pm 0.004$ \\
\hline & 1.60 & $0.96^{\mathrm{d}} \pm 0.02$ & $2.88^{d} \pm 0.05$ & $383^{c} \pm 14$ & $0.110^{\mathrm{e}} \pm 0.002$ \\
\hline \multirow{6}{*}{ con 15} & 0.00 & $0.62^{a} \pm 0.01$ & $1.75^{\mathrm{a}} \pm 0.04$ & $305^{a} \pm 8$ & $0.048^{a} \pm 0.001$ \\
\hline & 0.13 & $0.65^{\mathrm{ab}} \pm 0.02$ & $1.93^{\mathrm{a}} \pm 0.14$ & $315^{a} \pm 3$ & $0.060^{b} \pm 0.002$ \\
\hline & 0.40 & $0.71^{b} \pm 0.01$ & $2.22^{b} \pm 0.09$ & $317^{a} \pm 9$ & $0.066^{\mathrm{c}} \pm 0.001$ \\
\hline & 0.80 & $0.80^{c} \pm 0.03$ & $2.37^{b} \pm 0.13$ & $339^{b} \pm 6$ & $0.072^{\mathrm{d}} \pm 0.003$ \\
\hline & 1.07 & $0.88^{d} \pm 0.00$ & $2.75^{c} \pm 0.07$ & $367^{c} \pm 6$ & $0.079^{\mathrm{e}} \pm 0.003$ \\
\hline & 1.60 & $0.95^{\mathrm{e}} \pm 0.03$ & $2.95^{c} \pm 0.08$ & $398^{\mathrm{d}} \pm 3$ & $0.092^{f} \pm 0.004$ \\
\hline
\end{tabular}

All data are means of three independent measurements \pm std of 3 bottles treated in each HRL concentration of two equally sized batches of wines. Different superscript capital letters in the same column and for each wine (+ treatments) are significantly different $(p<0.05)$ by Tukey HSD Test. ${ }^{a}$ : Source of variation different wine samples (1st column) vs. HRL treatments

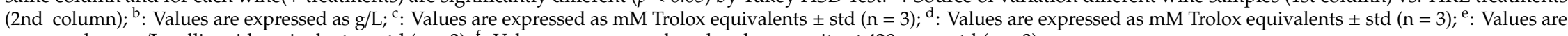
expressed as $\mathrm{mg} / \mathrm{L}$ gallic acid equivalents $\pm \operatorname{std}(n=3) ;$ f: Values are expressed as absorbance units at $420 \mathrm{~nm} \pm \operatorname{std}(n=3)$. 


\subsection{Antioxidant Capacity}

The effect on the antioxidant capacity of the treated wines was monitored through the inhibition of the DPPH radical and the Ferric Reducing Antioxidant Power as described below.

\subsubsection{Radical Scavenging Activity as Determined by the Inhibition of the DPPH Radical Assay}

The free radical scavenging activity prior and after HRL treatments was evaluated by the DPPH assay [48]. The DPPH assay relies on the neutralization of a methanol-soluble stable radical by direct reduction via electron transfer or by radical quenching via $\mathrm{H}$ atom transfer even though the latter could be considered as marginal reaction since it occurs very slowly in methanol [49].

It was observed that the radical scavenging activity of the treated wines increased linearly with the relevant increase in the HRL amount. The equations of radical scavenging activity as determined with the DPPH Assay $\left(\mathrm{A}_{\mathrm{AR}}\right)$ for the wines treated and HRL amount $(\mathrm{x})$ are presented in Figure 1. Regression analysis indicates that the $\mathrm{A}_{\mathrm{AR}}$ correlated well with the amount of HRL added.

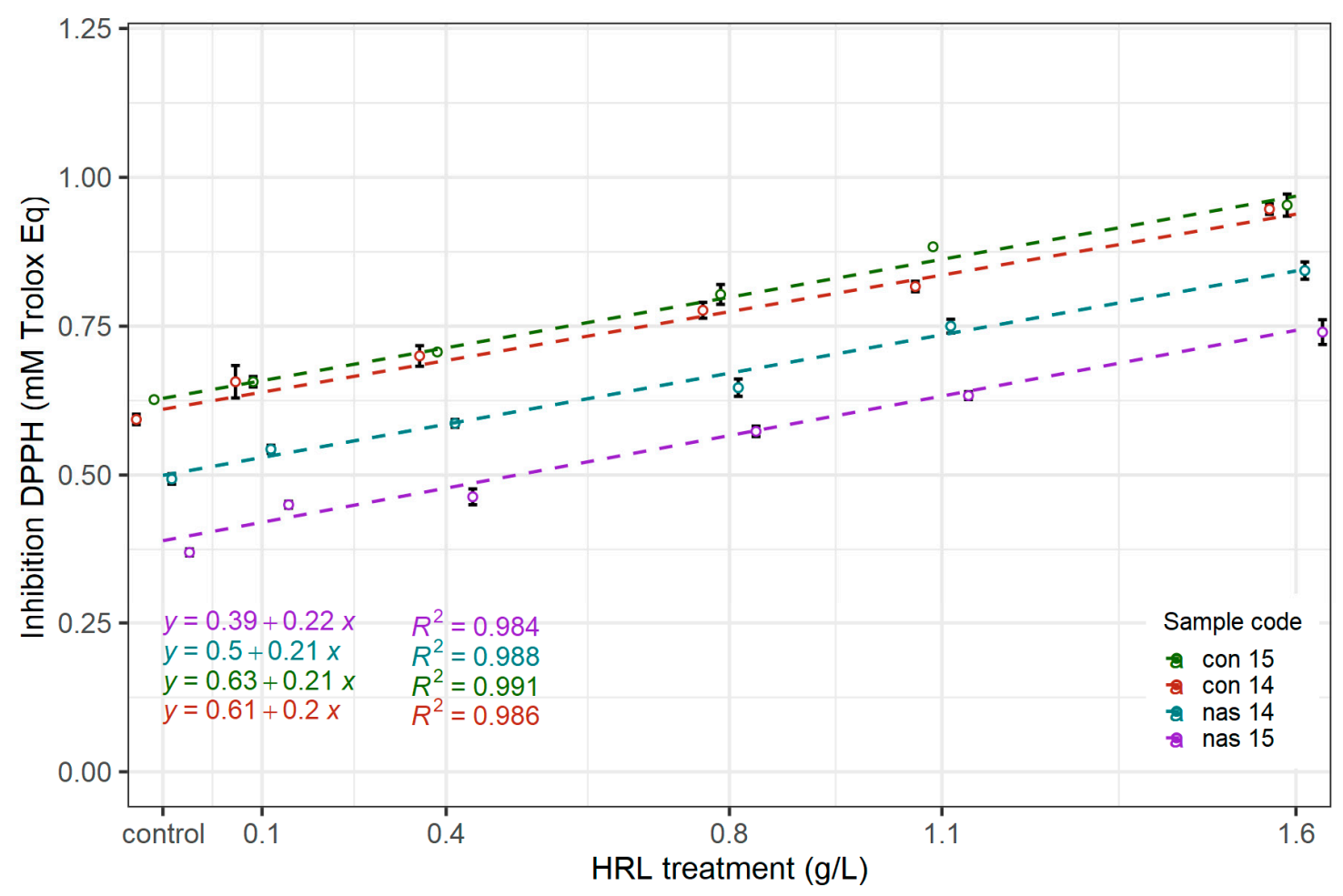

Figure 1. Radical Scavenging Activity via the inhibition of the DPPH radical vs. increasing HRL treatments in each wine. Error bars correspond to the standard error of the mean.

The conventional white vinifications of the same parcel in the two vintages examined, exhibited similar values of initial antioxidant capacity $\left(\mathrm{A}_{\mathrm{AR} \text { con 15 }}: 0.62 \pm 0.01 \mathrm{mM} \mathrm{TE} ; \mathrm{A}_{\mathrm{AR} \text { con 14: }}: 0.59 \mathrm{mM} \pm 0.01 \mathrm{TE}\right)$ considerably higher than the sulphite free vinifications $\left(\mathrm{A}_{\mathrm{AR} \text { nas15 }}: 0.37 \pm 0.01 \mathrm{mM} \mathrm{TE} ; \mathrm{A}_{\mathrm{AR} \text { nas14 }}\right.$ : $0.49 \pm 0.01 \mathrm{mM}$ TE). Differences in the $\mathrm{A}_{\mathrm{AR}}$ among sulphite free samples can be attributed to various factors such as vintage, vinification protocol, or oxygen uptake [2].

As presented in Table 4, treatment with $0.8 \mathrm{~g} / \mathrm{L}$ HRL resulted in an increase in $\mathrm{A}_{\mathrm{AR}}$ by 30.8 to $55.8 \%$ for sulphite-free vinifications and 28.4 to $31.2 \%$ for conventional vinifications. Treatment with $1.6 \mathrm{~g} / \mathrm{L}$ resulted in an increase ranging from $52.6 \%$ to $100.1 \%$.

A treatment of $0.8 \mathrm{~g} / \mathrm{L}$ of HRL increased the radical scavenging activity of the wines without added sulphites to the level of the above mentioned activity of conventional wines indicating that HRL can have a positive effect on the $\mathrm{A}_{\mathrm{AR}}$ of white wines. The increase in antioxidant capacity of the samples was expected since aqueous and hydroalcoholic extracts of $H$. rhamnoides leaves have been found to exhibit potent antioxidant capacity [19]. It must be noted however, that it would require at 
least a 4 fold dose of the powdered HRL used in this study on the nas samples in order to reach the levels of Aar of conventional samples $\left(0.4 \mathrm{~g} / \mathrm{L}\right.$ of HRL versus $115 \mathrm{ppm}$ as Total $\mathrm{SO}_{2}$ ) demonstrating that sulphur dioxide was found to be a significantly more powerful radical scavenger than the HRL.

Published data by Psarra et al. (2002) on the radical scavenging activity of 26 conventional commercial Greek white wines through the DPPH assay ranged from 0.47 to $0.60 \mathrm{mM}$ TE (mean value: $0.52 \mathrm{mM} \mathrm{TE}$ ) which were similar to the present study (range 0.43-0.62 mM TE; mean value $0.55 \mathrm{mM} \mathrm{TE}$ ) but with minor differences on the assay protocol. On the same study [50] the authors reports values ranging from 0.53 to $0.58 \mathrm{mM}$ TE for Moschofilero varietal wines.

Proestos et al. (2015) [46] reported that a $0.3 \mathrm{~g} / \mathrm{L}$ HRL treatment on a white wine made from cv. Savatiano resulted approximately in 3.5 fold increase in the wine antioxidant capacity as determined with the DPPH assay. A direct comparison among studies would not be considered as appropriate since in studies where biological raw materials are involved, numerous parameters may be simultaneously different $[19,51]$. Previously published data indicate that the bioactive profile of the leaves can vary significantly according to cultivar of interest [27], sex [52], seasonal variation, cultivation practices, maturity level [24], and time of harvest [52,53]. Thermal processing and grinding also play a key role. As Guan et al. (2006) reported, drying temperatures of $80-100{ }^{\circ} \mathrm{C}$ reduce the extractable bioactive mass available in comparison to the conditions adopted in the current study $\left(50-60{ }^{\circ} \mathrm{C}\right)$ [31] while Morgenstern et al. 2015 reported that fine grinding of the leaves resulted in a considerably improved extractability in comparison to using intact leaves [54].

In a former study in our lab, Roidaki et al. (2015) [55] determined the antioxidant activity in extracts of different species of $H$. rhamnoides leaves showing their potent antioxidant properties. Unfortunately, a screening of the bioactive compounds present in the HRL used in this study, and their extraction over time and temperature, which would enable us to thoroughly examine their contribution was not conducted at the time of the study.

\subsubsection{Reducing Capacity as Determined by the FRAP Assay}

FRAP values prior HRL treatments ranged from 1.13 to $1.75 \mathrm{~mm}$ TE. Treatment with $0.8 \mathrm{~g} / \mathrm{L}$ increased FRAP values from 35.3 to $62.1 \%$ whereas $1.6 \mathrm{~g} / \mathrm{L}$ almost doubled the initial FRAP values. The increase in ferric reducing power is depicted graphically in Figure 2. Correlation coefficients $\left(R^{2}\right)$ ranged from 0.969 to 0.989 denoting a good correlation between FRAP values of the wine samples and HRL additions. As expected, sulphite free vinifications demonstrated considerably lower FRAP values. Depending on the sample, an HRL treatment ranging from 0.4 to $0.8 \mathrm{~g} / \mathrm{L}$ would be required to increase FRAP values to the level of the sulphited samples.

Values of the wine samples prior to the HRL treatments are in the range of previously published literature. Stratil et al. (2008) [56] reported FRAP values ranging from 0.86 to $2.14 \mathrm{mM}$ TE for 8 commercial white wines from the Czech Republic whereas Proestos et al. (2015) [46] reported a FRAP value equal to $1.79 \mathrm{mM}$ TE for a Greek white wine from Savatiano grapes. 


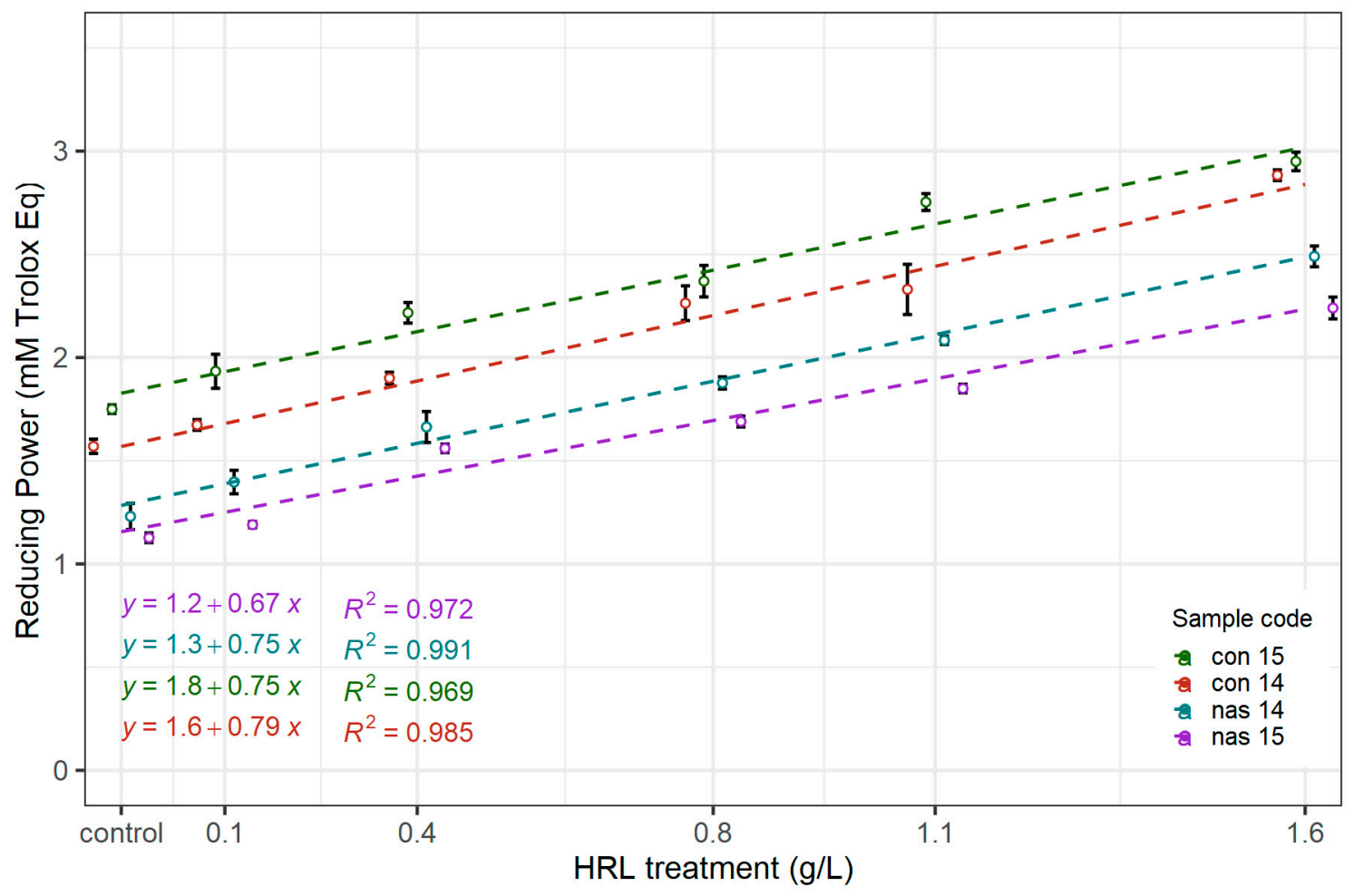

Figure 2. Ferric Reducing Antioxidant Power vs. increasing HRL treatments in each wine. Error bars correspond to the standard error of the mean.

\subsection{Total Phenol Content}

The contribution of phenolic compounds to the antioxidant activity of wines is considered crucial even though in some cases it is overestimated [7]. The concentration of different phenolic compounds varies significantly within wines from the same variety according to various factors such as vintage year, soil composition and climatic conditions. Moreover, significant changes may occur in the composition and content of phenolic compounds as a result of the vinification, maturation, and bottle storage [2,47].

The total phenol content of the wine samples prior HRL treatments ranged from 220 to $305 \mathrm{mg} / \mathrm{L}$ GAE. HRL treatments provoked a linear positive response to the values of TPC. The increase in TPC is demonstrated graphically in Figure 3. Correlation coefficients $\left(R^{2}\right)$ were in the range of 0.974 to 0.988 denoting a good correlation between TPC of wine samples and HRL additions. Treatments with $0.8 \mathrm{~g}$ $\mathrm{HRL} / \mathrm{L}$ resulted in a 11.3 to $20.1 \%$ increase in TPC values in comparison to the initial values whereas treatment with $1.6 \mathrm{~g} / \mathrm{L}$ HRL resulted in a mean $37.5 \%$ increase in TPC values.

The increase in total phenol content of the samples was expected since aqueous and hydroalcoholic extracts of $H$. rhamnoides leaves have been found to contain significant quantities of bioactive phenolic compounds such as quercetin-3-O-galactoside, quercetin-3-O-glucoside, kaempferol, and isorhamnetin [22]. Ma et al. [18] report that beverages in the form of tea-type infusions of HRL were found rich in flavonol glycosides, mainly derivatives of quercetin kaempferol and isorhamnetin as well elagitannins, namely Casuarictin, Casuarinin, Hippophaenin B, Hippophaenin C, Pedunculagin, and Stachyurin. Values of $40.49 \mathrm{mg}$ gallic acid/g dry leaf for aqueous extracts and $56.28 \mathrm{mg}$ gallic acid/g dry leaf for hydroalcoholic leaf extracts have been previously reported [22]. A detailed description regarding to the phenolic content and the whole chemical profile of HRL can be found in a recent review by Ciesarová et al. [17].

TPC values prior HRL additions were in the range of previously published data. Stasko et al. (2008) [57] report values for Slovakian and Austrian white wines ranging from 210 to $390 \mathrm{mg}$ GAE/L while Roussis et al. (2008) [58] report values ranging from 213 to 277 mg GAE/L. 
Results above imply that the use of HRL in the above concentrations in red wines in this stage would have had a limited contribution comparing to their natural antioxidant properties and total phenolic content [56-58].

It was not possible to compare the results for the DPPH, FRAP assays, and total phenol content on the wines after the HRL treatments since relevant bibliographic references were not found available.

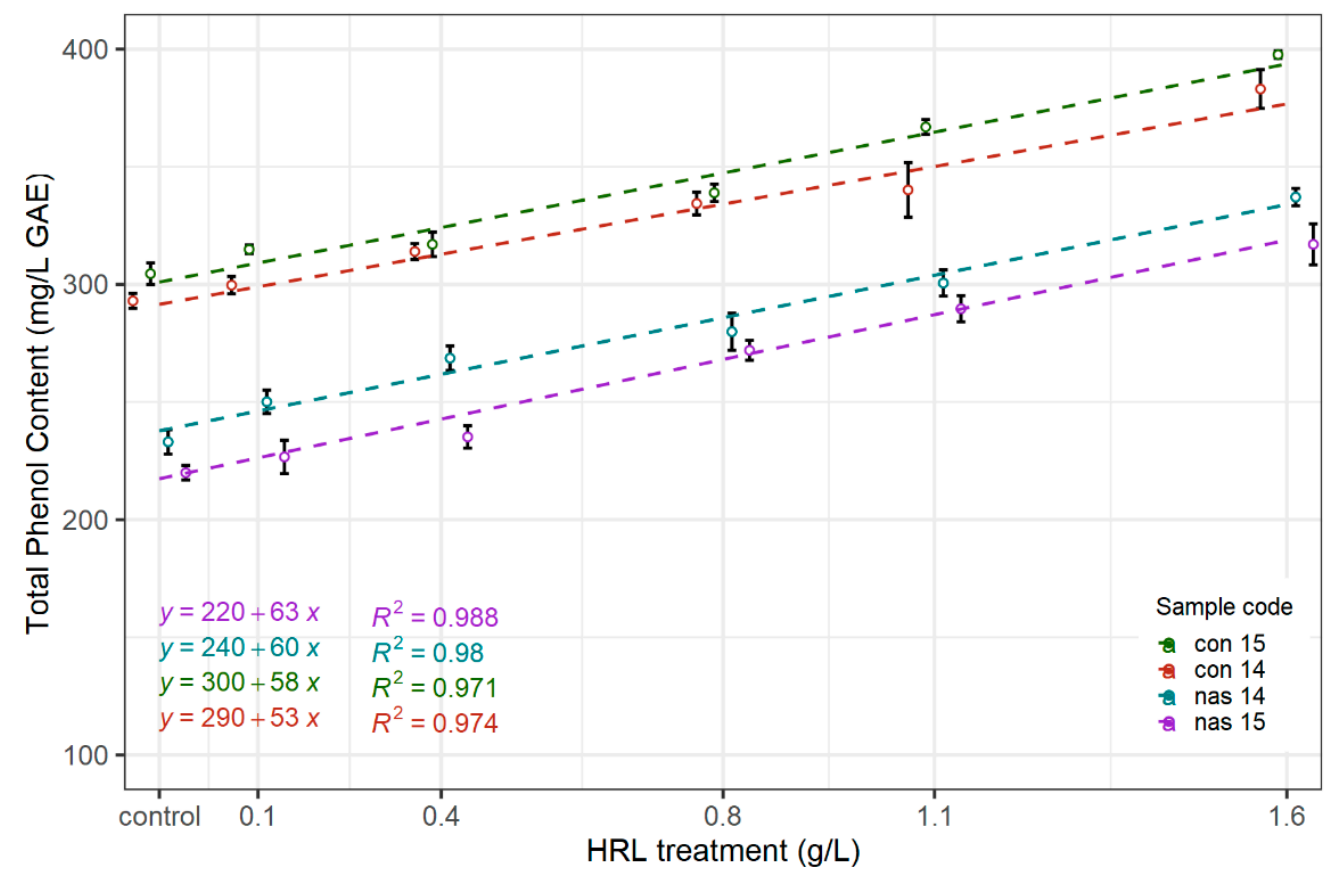

Figure 3. Total Phenol Content of wine samples vs. increasing HRL treatments in each wine. Error bars correspond to the standard error of the mean.

\subsection{Correlation Analysis}

Correlation analysis was used to determine the relationships amongst the different antioxidant parameters measured for all wine samples via Pearson correlation coefficient (Table 5). The total phenolic content of wine samples exhibited a very good correlation $(p<0.01)$ with antioxidant properties. These findings are in accordance with previously published literature [59].

Table 5. Correlation between antioxidant assays and Total phenol content via Pearson Correlation Coefficient (Correlation is significant at the 0.01 level).

\begin{tabular}{cccc}
\hline & DPPH & FRAP & TPC \\
\hline DPPH & 1 & & \\
FRAP & 0.96 & 1 & \\
TPC & 0.95 & 0.94 & 1 \\
\hline
\end{tabular}

\subsection{Sensory Evaluation}

Sensory characteristics of wines examined prior and after HRL treatments are presented in the barplots (Figure 4a-d). Wines from the Moschofilero variety are regarded as highly aromatic, hence they were chosen to assess the extent of the effect of the HRL treatments to their organoleptic properties. 


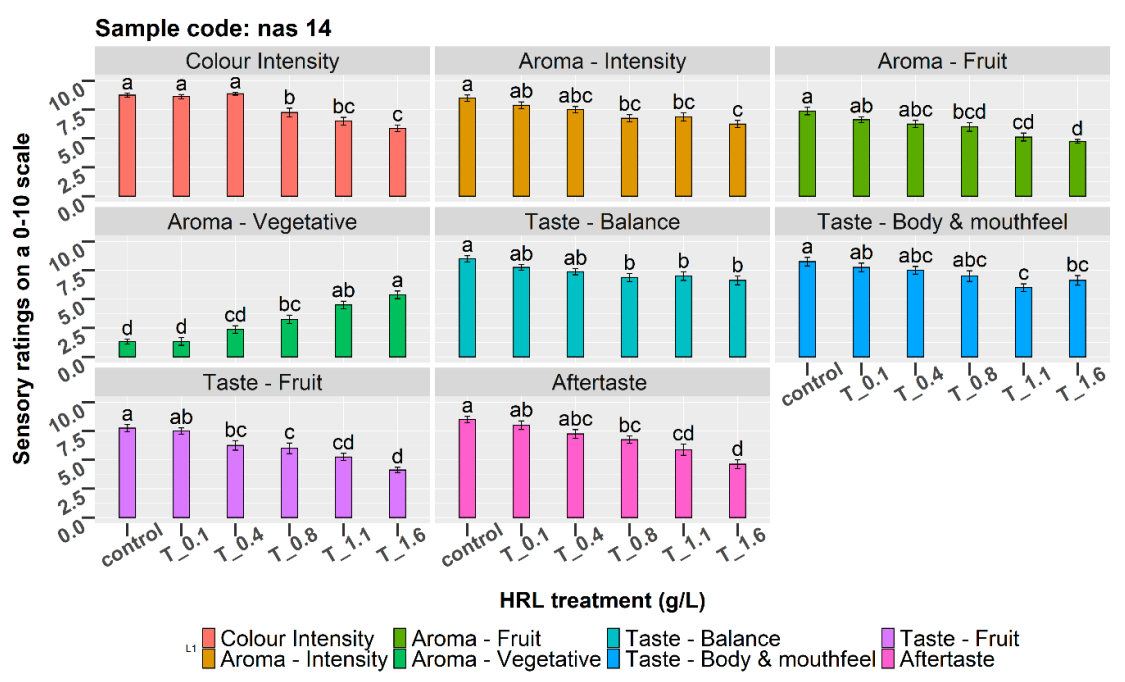

(a)

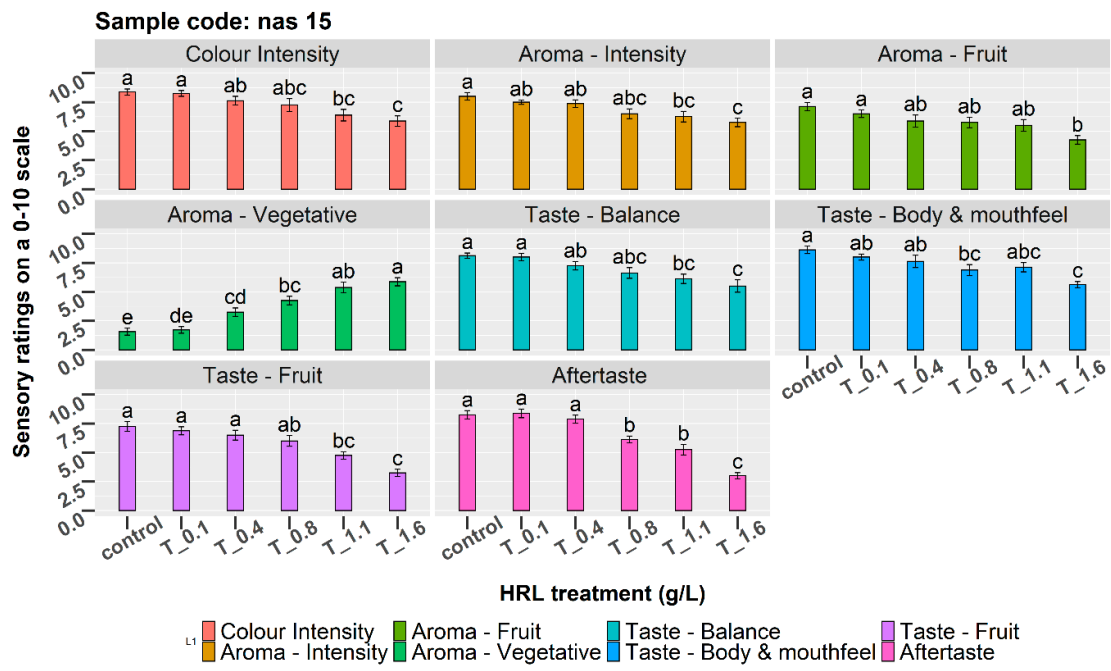

(b)

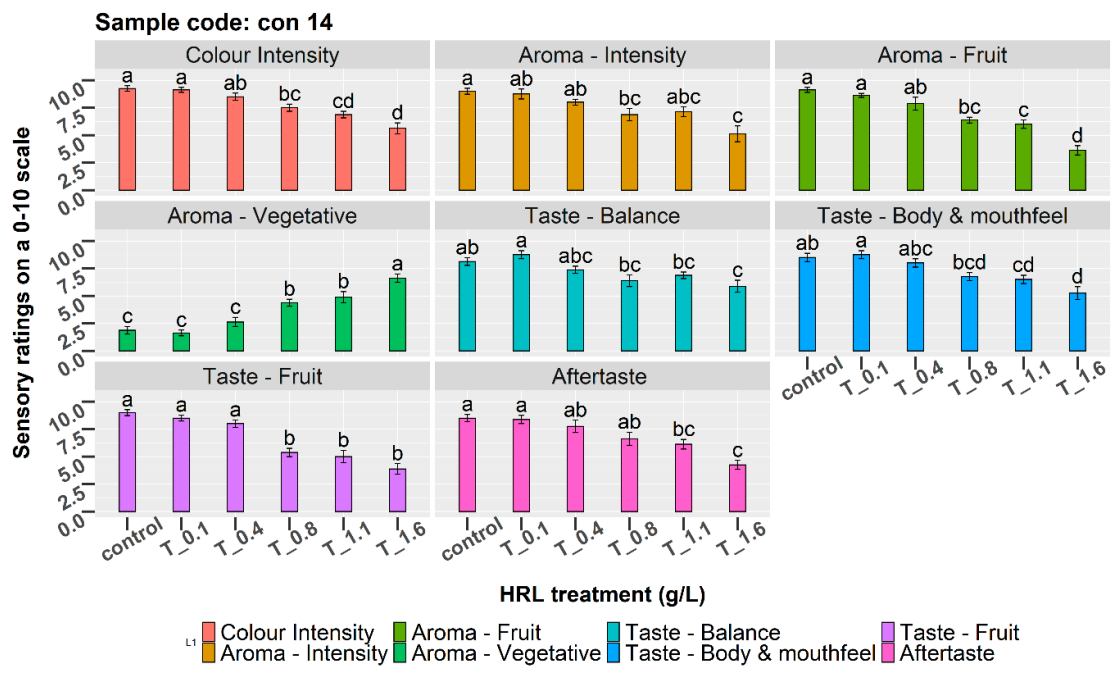

(c)

Figure 4. Cont. 


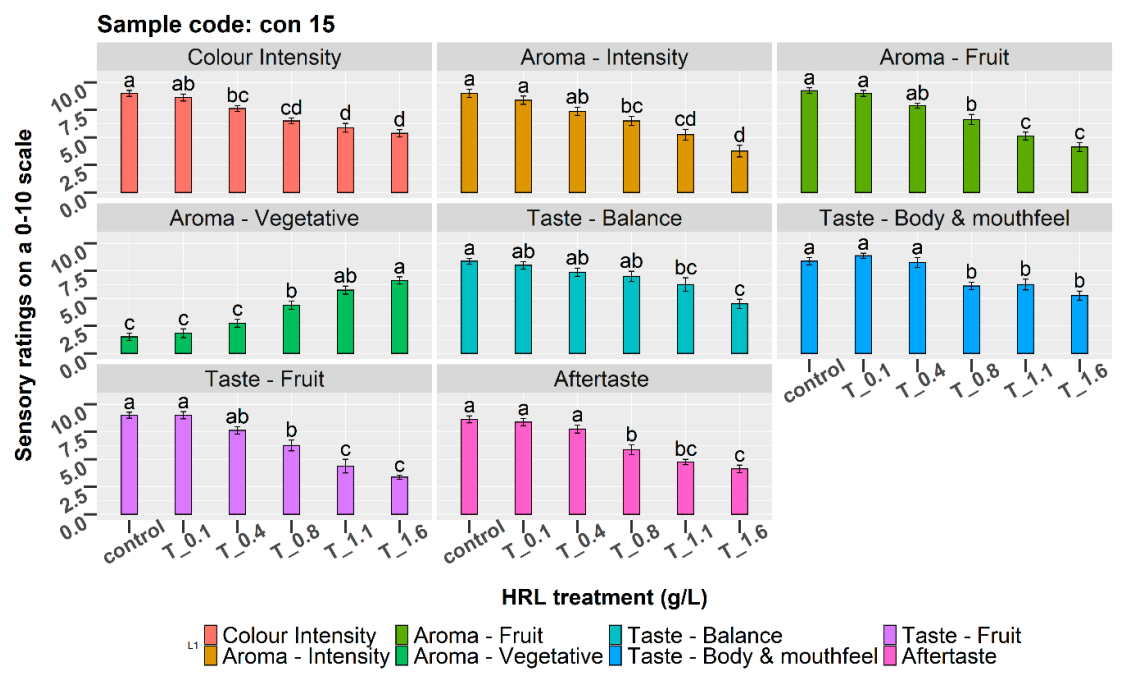

(d)

Figure 4. Sensory evaluation barplots of varietal Moschofilero wines (samples codes: (a) nas14, (b) nas15, (c) con14, (d) con15) treated with increasing quantities of HRL. Abbreviations; nas 14 (vinification without added sulphites, vintage 2014); nas 15 vinification without added sulphites, vintage 2015); con14 (conventional vinification, vintage 2014); (conventional vinification, vintage 2015); T_0.1-T_1.6: Increasing HRL treatments from 0.1 to $1.6 \mathrm{~g} / \mathrm{L}$; Different letters among columns of the same color denote significant $(p<0.05)$ statistical differences.

Treatment with $0.4 \mathrm{~g} / \mathrm{L}$ HRL did not have a major impact on the sensory profile of the wines, resulting in minor changes in the ratings of the descriptors examined (e.g., minor decrease in fruity character rating in nas 14 , decrease in color ratings in samples nas15, con14, con15) in comparison to the control samples which were not found to be statistically significant $(p>0.05)$. Treatments with 0.8 $\mathrm{g} / \mathrm{L}$ of HRL resulted in a statistically significant change on the ratings of specific descriptors, specifically decrease in color and fruit character ratings for sulphited samples con14 and con15, increase in vegetative character for all samples as well as decrease in balance ratings for all samples, and the latter was not found to be statistically significant. Lastly, treatment with $1.6 \mathrm{~g} / \mathrm{L}$ of HRL had a detrimental effect on the sensory profile of all the wines tasted since relatively large and statistically significant changes were observed in comparison to the ratings of control samples on the majority of descriptors examined, namely decrease in color, fruit, balance, and increase on the vegetative character ratings of all samples.

\subsection{Possible Use in Winemaking}

The proposed treatment cannot be currently used on field trials since the treatment of wines with $H$. rhamnoides leaves is not listed in the authorized oenological practices and processes in EC Reg. 934/2019 [34]. Analogous efforts with other non-authorized plant phenolic extracts (eykalyptus and almond extracts) used as possible wine preservatives have been reported in the past [60]. However, we suggest that this study can be considered as a starting point for future optimization studies.

Regarding to the safety evaluation assessment of the proposed treatment, to the best of our knowledge no studies exist in the literature that deem the use of HRL hazardous for human consumption. To the contrary, relevant reports available indicate that no cytotoxicity has been observed nor adverse effects on rats after oral administration of $H$. rhamnoides leaves $[21,28,29]$. Indicatively, on a previous safety evaluation study by Saggu et al. [28] on rats treated with aqueous extracts of HRL, the results evidenced that no toxicity was observed even after a sub-acute (30 days) maximal effective dose administration of $10 \mathrm{~g} / \mathrm{kg}$ body weight. Moreover, on the same study no changes were observed in any of the biochemical parameters studied after a dose of $2 \mathrm{~g} / \mathrm{kg}$ body weight for 14 days which is significantly higher than the doses proposed in this study. Similarly, Singh et al. (2014), after studying 
acute and subacute effects of pharmacologically active HRL, reported that a $75 \%$ ethanolic extract of HRL was found to be practically nontoxic; the latter concluded, however, that further studies are needed to confirm long term toxicities [61].

\section{Conclusions}

Experimental data above suggest that the treatment with $H$. rhamnoides leaves on dry white wines vinified with and without added sulphites contributed positively and in a linear manner to the overall antioxidant capacity, total phenolic content, and ferric reducing antioxidant power of the samples tested. It must be noted nonetheless that factors such as the genetic variability, seasonal variation, agricultural practices, as well as processing methods can significantly affect the availability and composition of the bioactive matter in the raw materials. Sulphur dioxide was proven to be significantly more effective in determining the antioxidant capacity of the wine samples. To the best of our knowledge this is the first study regarding the evaluation of the effect of increasing HRL treatments as an alternative means to increase the antioxidant capacity of wines.

The main oenological attributes examined, except for color intensity (absorbance at $420 \mathrm{~nm}$ ), remained unchanged. On a sensory aspect, treatments up to $0.4 \mathrm{~g} / \mathrm{L}$ HRL had a marginal sensory effect on the samples tasted whereas treatments higher than $0.8 \mathrm{~g} / \mathrm{L}$ of HRL resulted in a decrease in the rating of all sensory characteristics of the wines examined.

Current winemaking trends promote the reduced use or even absence of $\mathrm{SO}_{2}$ additions in winemaking, constituting the research for $\mathrm{SO}_{2}$ alternatives as a continuous effort. Various strategies have been proposed, mainly employing physical and/or chemical methods, subsequently tested and evaluated for approval. A full replacement of sulphur dioxide by a single additive has not been accomplished. Our findings suggest that the use of HRL on white wines is a promising step towards this direction and this would be particularly helpful in increasing the antioxidant capacity of wines without added sulphites. However, the treatment with HRL is not currently authorized for use in winemaking and safety experiments would be needed before any possible use in on field applications. The authors suggest that further optimization studies on the use of HRL (effectiveness among different species and/or other extracts, effect on wine microbiology, treatments with greater concentrations in red wines, treatments in different stages of the vinification process, synergistic effects with other antioxidant/antimicrobial agents) as well as the implementation of a specific context for their use in winemaking should be considered in the future.

Author Contributions: P.T. and C.P. conceived the study; P.T. and A.T. contributed to the study design; A.C.C., M.L., P.T. and C.P. coordinated the study; A.T. conducted the vinifications and wine treatments; A.T. and K.P. performed the analytical determinations and analyzed the data; A.T. prepared the original draft; A.T. prepared the revised version. All authors edited the paper. All authors have read and agreed to the published version of the manuscript.

Funding: This research received no external funding.

Acknowledgments: The authors would like to express their gratitude to P. Zamanidis from ELGO DIMITRA for the provision and characterization of the plant material and the Boutari s.a. (Naoussa, Greece) for the provision of resources regarding the vinification of the wine samples

Conflicts of Interest: The authors declare no conflict of interest.

\section{References}

1. Li, H.; Guo, A.; Wang, H. Mechanisms of oxidative browning of wine. Food Chem. 2008, 108, 1-13. [CrossRef]

2. Lingua, M.S.; Fabani, M.P.; Wunderlin, D.A.; Baroni, M.V. From grape to wine: Changes in phenolic composition and its influence on antioxidant activity. Food Chem. 2016, 208, 228-238. [CrossRef]

3. Monagas, M.; Bartolomé, B.; Gómez-Cordovés, C. Updated knowledge about the presence of phenolic compounds in wine. Crit. Rev. Food Sci. Nutr. 2005, 45, 85-118. [CrossRef] [PubMed]

4. Abramovič, H.; Košmerl, T.; Poklar Ulrih, N.; Cigić, B. Contribution of $\mathrm{SO}_{2}$ to antioxidant potential of white wine. Food Chem. 2015, 174, 147-153. [CrossRef] [PubMed] 
5. Di Mattia, C.D.; Piva, A.; Martuscelli, M.; Mastrocola, D.; Sacchetti, G. Effect of sulfites on the in vitro antioxidant activity of wines. Ital. J. Food Sci. 2015, 27, 505-512.

6. Oliveira, C.M.; Ferreira, A.C.S.; De Freitas, V.; Silva, A.M.S. Oxidation mechanisms occurring in wines. Food Res. Int. 2011, 44, 1115-1126. [CrossRef]

7. Danilewicz, J.C. Folin-Ciocalteu, FRAP, and DPPH• assays for measuring polyphenol concentration in white wine. Am. J. Enol. Vitic. 2015, 66, 463-471. [CrossRef]

8. Ribéreau-Gayon, P.; Glories, Y.; Maujean, A.; Dubourdieu, D. Handbook of Enology; John and Wiley and Sons: Hoboken, NJ, USA, 2006; Volume 2.

9. Vally, H.; Misso, N.L.A.; Madan, V. Clinical effects of sulphite additives. Clin. Exp. Allergy 2009, 39, $1643-1651$. [CrossRef]

10. Webber, V.; Dutra, S.V.; Spinelli, F.R.; Marcon, Â.R.; Carnieli, G.J.; Vanderlinde, R. Effect of glutathione addition in sparkling wine. Food Chem. 2014, 159, 391-398. [CrossRef]

11. Bekker, M.Z.; Smith, M.E.; Smith, P.A.; Wilkes, E.N. Formation of hydrogen sulfide in wine: Interactions between copper and sulfur dioxide. Molecules 2016, 21, 1214. [CrossRef]

12. Chagas, R.; Ferreira, L.M.; Laia, C.A.T.; Monteiro, S.; Ferreira, R.B. The challenging SO2-mediated chemical build-up of protein aggregates in wines. Food Chem. 2016, 192, 460-469. [CrossRef] [PubMed]

13. Lustrato, G.; Alfano, G.; Belli, C.; Grazia, L.; Iorizzo, M.; Ranalli, G. Scaling-up in industrial winemaking using low electric current as an alternative to sulfur dioxide addition. J. Appl. Microbiol. 2006, 101, 682-690. [CrossRef] [PubMed]

14. Santos, M.C.; Nunes, C.; Saraiva, J.A.; Coimbra, M.A. Chemical and physical methodologies for the replacement/reduction of sulfur dioxide use during winemaking: Review of their potentialities and limitations. Eur. Food Res. Technol. 2012, 234, 1-12. [CrossRef]

15. Sonni, F.; Bastante, M.J.C.; Chinnici, F.; Natali, N.; Riponi, C. Replacement of sulfur dioxide by lysozyme and oenological tannins during fermentation: Influence on volatile composition of white wines. J. Sci. Food Agric. 2009, 89, 688-696. [CrossRef]

16. Pati, S.; Crupi, P.; Benucci, I.; Antonacci, D.; Di Luccia, A.; Esti, M. HPLC-DAD-MS/MS characterization of phenolic compounds in white wine stored without added sulfite. Food Res. Int. 2014, 66, 207-215. [CrossRef]

17. Ciesarová, Z.; Murkovic, M.; Cejpek, K.; Kreps, F.; Tobolková, B.; Koplík, R.; Belajová, E.; Kukurová, K.; Daško, L.; Panovská, Z.; et al. Why is sea buckthorn (Hippophae rhamnoides L.) So exceptional? A review. Food Res. Int. 2020, 133, 109170. [CrossRef]

18. Ma, X.; Moilanen, J.; Laaksonen, O.; Yang, W.; Tenhu, E.; Yang, B. Phenolic compounds and antioxidant activities of tea-type infusions processed from sea buckthorn (Hippophaë rhamnoides) leaves. Food Chem. 2019, 272, 1-11. [CrossRef]

19. Yogendra Kumar, M.S.; Tirpude, R.J.; Maheshwari, D.T.; Bansal, A.; Misra, K. Antioxidant and antimicrobial properties of phenolic rich fraction of Seabuckthorn (Hippophae rhamnoides L.) leaves in vitro. Food Chem. 2013, 141, 3443-3450. [CrossRef]

20. Michel, T.; Destandau, E.; Le Floch, G.; Lucchesi, M.E.; Elfakir, C. Antimicrobial, antioxidant and phytochemical investigations of sea buckthorn (Hippophä̈ rhamnoides L.) leaf, stem, root and seed. Food Chem. 2012, 131, 754-760. [CrossRef]

21. Wani, T.A.; Wani, S.M.; Ahmad, M.; Ahmad, M.; Gani, A.; Masoodi, F.A. Bioactive profile, health benefits and safety evaluation of sea buckthorn (Hippophae rhamnoides L.): A review. Cogent Food Agric. 2016, 2, 1128519. [CrossRef]

22. Upadhyay, N.K.; Yogendra Kumar, M.S.; Gupta, A. Antioxidant, cytoprotective and antibacterial effects of Sea buckthorn (Hippophae rhamnoides L.) leaves. Food Chem. Toxicol. 2010, 48, 3443-3448. [CrossRef] [PubMed]

23. Singh, I.P.; Ahmad, F.; Gore, D.D.; Tikoo, K.; Bansal, A.; Jachak, S.M.; Jena, G. Therapeutic potential of seabuckthorn: A patent review (2000-2018). Expert Opin. Ther. Pat. 2019, 29, 733-744. [CrossRef] [PubMed]

24. Morgenstern, A.; Ekholm, A.; Scheewe, P.; Rumpunen, K. Changes in content of major Phenolic compounds during leaf development of sea buckthorn (Hippophaë rhamnoides L.). Agric. Food Sci. 2014, 23, 207-219. [CrossRef]

25. Pop, R.M.; Socaciu, C.; Pintea, A.; Buzoianu, A.D.; Sanders, M.G.; Gruppen, H.; Vincken, J. UHPLC/PDA-ESI/MS analysis of the main berry and leaf flavonol glycosides from different Carpathian Hippophaë rhamnoides L. varieties. Phytochem. Anal. 2013, 24, 484-492. [CrossRef] 
26. Pop, R.M.; Buzoianu, A.D.; Rati, I.V.; Socaciu, C. Untargeted metabolomics for sea buckthorn (Hippophae Rhamnoides ssp. carpatica) berries and leaves: Fourier transform infrared spectroscopy as a rapid approach for evaluation and discrimination. Not. Bot. Horti Agrobot. Cluj-Napoca 2014, 42, 545-550. [CrossRef]

27. Criste, A.; Urcan, A.C.; Bunea, A.; Furtuna, F.R.P.; Olah, N.K.; Madden, R.H.; Corcionivoschi, N. Phytochemical composition and biological activity of berries and leaves from four romanian sea buckthorn (Hippophae Rhamnoides L.) varieties. Molecules 2020, 25, 1170. [CrossRef]

28. Saggu, S.; Divekar, H.M.; Gupta, V.; Sawhney, R.C.; Banerjee, P.K.; Kumar, R. Adaptogenic and safety evaluation of seabuckthorn (Hippophae rhamnoides) leaf extract: A dose dependent study. Food Chem. Toxicol. 2007, 45, 609-617. [CrossRef]

29. Tulsawani, R. Ninety day repeated gavage administration of Hipphophae rhamnoides extract in rats. Food Chem. Toxicol. 2010, 48, 2483-2489. [CrossRef]

30. Adadi, P.; Kovaleva, E.G.; Glukhareva, T.V.; Shatunova, S.A.; Petrov, A.S. Production and analysis of non-traditional beer supplemented with sea buckthorn. Agron. Res. 2017, 15, 1831-1845.

31. Guan, T.T.Y.; Cenkowski, S.; Hydamaka, A. Effect of Drying on the Nutraceutical Quality of Sea Buckthorn (Hippophae rhamnoides L. ssp. sinensis) Leaves. J. Food Sci. 2006, 70, E514-E518. [CrossRef]

32. Pop, R.M.; Weesepoel, Y.; Socaciu, C.; Pintea, A.; Vincken, J.P.; Gruppen, H. Carotenoid composition of berries and leaves from six Romanian sea buckthorn (Hippophae rhamnoides L.) varieties. Food Chem. 2014, 147, 1-9. [CrossRef] [PubMed]

33. Bittová, M.; Krejzová, E.; Roblová, V.; Kubán, P.; Kubáň, V. Monitoring of HPLC profiles of selected polyphenolic compounds in sea buckthorn (Hippophä rhamnoides L.) plant parts during annual growth cycle and estimation of their antioxidant potential. Cent. Eur. J. Chem. 2014, 12, 1152-1161. [CrossRef]

34. European Commission Comission delegated Regulation (EU). 2019/934 of 12 March 2019 supplementing Regulation (EU) No 1308/2013 of the European Parliament and of the Council as regards wine-growing areas where the alcoholic strength may be increased, authorised oenological prac. Off. J. Eur. Union L. 2019, 149, $1-52$.

35. Scrimgeour, N.; Nordestgaard, S.; Lloyd, N.D.R.; Wilkes, E.N. Exploring the effect of elevated storage temperature on wine composition. Aust. J. Grape Wine Res. 2015, 21, 713-722. [CrossRef]

36. OIV. OIV (Organisation International de la Vigne et du Vin) Sulfur Dioxide, (Iodometry), Methode OIV-MA-AS323-04B. Compend. Int. Methods Anal. Wines Musts 2009, 2, 291-294.

37. Castillo-Sánchez, J.J.; Mejuto, J.C.; Garrido, J.; García-Falcón, S. Influence of wine-making protocol and fining agents on the evolution of the anthocyanin content, colour and general organoleptic quality of Vinhão wines. Food Chem. 2006, 97, 130-136. [CrossRef]

38. Porgali, E.; Büyüktuncel, E. Determination of phenolic composition and antioxidant capacity of native red wines by high performance liquid chromatography and spectrophotometric methods. Food Res. Int. 2012, 45, 145-154. [CrossRef]

39. Molyneux, P. The Use of the Stable Free Radical Diphenylpicryl-hydrazyl (DPPH) for Estimating Antioxidant Activity. Songklanakarin J. Sci. Technol. 2004, 26, 211-219.

40. Benzie, I.F.F.; Strain, J.J. The ferric reducing ability of plasma (FRAP) as a measure of "antioxidant power": The FRAP assay. Anal. Biochem. 1996, 239, 70-76. [CrossRef]

41. Danilewicz, J.C. Reactions involving iron in mediating catechol oxidation in model wine. Am. J. Enol. Vitic. 2013, 64, 316-324. [CrossRef]

42. Singleton, V.L.; Rossi, J.A. Colorimetry of Total Phenolics with Phosphomolybdic-Phosphotungstic Acid Reagents. Am. J. Enol. Vitic. 1965, 16, 144-158.

43. Lee, E.J.; Nomura, N.; Patil, B.S.; Yoo, K.S. Measurement of total phenolic content in wine using an automatic Folin-Ciocalteu assay method. Int. J. Food Sci. Technol. 2014, 49, 2364-2372. [CrossRef]

44. R Development Core Team. R: A Language and Environment for Statistical Computing; R Foundation for Statistical Computing: Vienna, Austria, 2020; Available online: http://www.R-project.org (accessed on 2 May 2020).

45. Wickham, H. ggplot2. Wiley Interdiscip. Rev. Comput. Stat. 2011, 3, 180-185. [CrossRef]

46. Proestos, C.; Sflomos, K.; Zoumpoulakis, P.; Tatarides, P.; Sinanoglou, V.J. Botanical Extracts Used as Wine Preservatives. Int. J. Agric. Sci. Food Technol. 2015, 007-011. [CrossRef]

47. Kallithraka, S.; Salacha, M.I.; Tzourou, I. Changes in phenolic composition and antioxidant activity of white wine during bottle storage: Accelerated browning test versus bottle storage. Food Chem. 2009, 113, 500-505. [CrossRef] 
48. Brand-Williams, W.; Cuvelier, M.E.; Berset, C. Use of a free radical method to evaluate antioxidant activity. LWT Food Sci. Technol. 1995, 28, 25-30. [CrossRef]

49. Huang, D.; Boxin, O.U.; Prior, R.L. The chemistry behind antioxidant capacity assays. J. Agric. Food Chem. 2005, 53, 1841-1856. [CrossRef]

50. Psarra, E.; Makris, D.P.; Kallithraka, S.; Kefalas, P. Evaluation of the antiradical and reducing properties of selected Greek white wines: Correlation with polyphenolic composition. J. Sci. Food Agric. 2002, 82, 1014-1020. [CrossRef]

51. Kyriakopoulou, K.; Pappa, A.; Krokida, M.; Detsi, A.; Kefalas, P. Effects of Drying and Extraction Methods on the Quality and Antioxidant Activity of Sea Buckthorn (Hippophae rhamnoides) Berries and Leaves. Dry. Technol. 2013, 31, 1063-1076. [CrossRef]

52. Górnaś, P.; Šne, E.; Siger, A.; Seglina, D. Sea buckthorn (Hippophae rhamnoides L.) leaves as valuable source of lipophilic antioxidants: The effect of harvest time, sex, drying and extraction methods. Ind. Crops Prod. 2014, 60, 1-7. [CrossRef]

53. Li, T.S.C.; Beveridge, T.H.J. Sea Buckthorn (Hippophae rhamnoides L.): Production and Utilization; NRC Research Press: Ottawa, SO, USA, 2003.

54. Morgenstern, A.; Ekholm, A.; Scheewe, P.; Rumpunen, K. Major phenolic compounds in processed sea buckthorn leaves. In Producing Sea Buckthorn of High Quality, Proceedings of the 3rd European Workshop on Sea Buckthorn EuroWorkS2014, Naantali, Finland, October 14-16, 2014; Kauppinen, S., Petruneva, E., Eds.; Natural Resources Institute Finland (Luke): Helsinki, Finland, 2015; Volume 31, pp. 74-77. Available online: http://urn.fi/URN:ISBN:978-952-326-035-1 (accessed on 2 May 2020).

55. Roidaki, A.; Zoumpoulakis, P.G.; Proestos, C. Comparison of extraction methods for the determination of antioxidant activity in extracts of Hippophae rhamnoides L. and Lippia citriodora. The effect of. Austin J Nutr. Food Sci. 2015, 3, 1057-1064.

56. Stratil, P.; Kubáň, V.; Fojtová, J. Comparison of the phenolic content and total antioxidant activity in wines as determined by spectrophotometric methods. Czech J. Food Sci. 2008, 26, 242-253. [CrossRef]

57. Staško, A.; Brezová, V.; Mazúr, M.; Čertík, M.; Kaliňák, M.; Gescheidt, G. A comparative study on the antioxidant properties of Slovakian and Austrian wines. LWT Food Sci. Technol. 2008, 41, 2126-2135. [CrossRef]

58. Roussis, I.G.; Lambropoulos, I.; Tzimas, P.; Gkoulioti, A.; Marinos, V.; Tsoupeis, D.; Boutaris, I. Antioxidant activities of some Greek wines and wine phenolic extracts. J. Food Compos. Anal. 2008, 21, 614-621. [CrossRef]

59. Paixão, N.; Perestrelo, R.; Marques, J.C.; Câmara, J.S. Relationship between antioxidant capacity and total phenolic content of red, rosé and white wines. Food Chem. 2007, 105, 204-214. [CrossRef]

60. González-Rompinelli, E.M.; Rodríguez-Bencomo, J.J.; García-Ruiz, A.; Sánchez-Patán, F.; Martín-Álvarez, P.J.; Bartolomé, B.; Moreno-Arribas, M.V. A winery-scale trial of the use of antimicrobial plant phenolic extracts as preservatives during wine ageing in barrels. Food Control 2013, 33, 440-447. [CrossRef]

61. Singh, A.K.; Attrey, D.P.; Deep, P.; Dubey, S.; Naved, T.; Roy, B. Acute \& sub-acute toxicity studies of pharmacologically active seabuckthorn leaf extract. Int. J. Pharm. Pharm. Sci. 2014, 6, 415-419.

(C) 2020 by the authors. Licensee MDPI, Basel, Switzerland. This article is an open access article distributed under the terms and conditions of the Creative Commons Attribution (CC BY) license (http://creativecommons.org/licenses/by/4.0/). 